\title{
CLAY MINERALS AND GAMMA-RAY SPECTROMETRY AS PALEOCLIMATIC INDICATORS IN THE GONDWANA'S SEDIMENTARY SEQUENCES, SANTA CATARINA, BRAZIL
}

\author{
Hérlon da Silva Costa ${ }^{1}$, Marivaldo dos Santos Nascimento² and Francisco José Fonseca Ferreira ${ }^{1}$
}

\begin{abstract}
This work presents clay minerals data and gamma spectrometry to accesses the paleoclimatic signature during the depositional transition from Taciba to the Rio Bonito Formation in the eastern edge of the Paraná Basin. Detrital illite content (50 to 60\%) and chemical index alteration indicates low-influence of chemical weathering. The eTh/K and eTh/eU ratios and detrital illite in the Rio Bonito Formation indicate a cold and dry climate during deposition. The contrast between the increase in eTh/K and eTh/eU ratios and the decrease in the illite content toward the top of the Rio Bonito Formation suggests progressively warmer and humid climatic conditions. The cycling in the eTh/K and eTh/eU ratios clearly indicate seasonal variations in temperature and leaching of $\mathrm{K}$ and $\mathrm{eU}$.
\end{abstract}

Keywords: paleoclimate, Rio do Sul Formation and Rio Bonito Formation, Paraná Basin.

RESUMO. Este trabalho apresenta dados de argilominerais e gamaespectrometria para acessar a assinatura paleoclimática durante a transição deposicional da Formação Taciba para a Formação Rio Bonito na borda leste da Bacia do Paraná. 0 conteúdo de ilita detrítica (50 a 60\%) e a alteração do índice químico indicam baixa influência do intemperismo químico. As relações eTh/K e eTh/eU e ilita detrítica na Formação Rio Bonito indicam um clima frio e seco durante a deposição. 0 contraste entre 0 aumento das razões eTh/K e eTh/eU e a diminuição do conteúdo de ilitas em direção ao topo da Formação Rio Bonito sugerem condições climáticas progressivamente mais quentes e úmidas. A ciclagem nas razões eTh/K e eTh/eU indica claramente variações sazonais na temperatura e lixiviação de $\mathrm{K}$ e eU.

Palavras-chave: paleoclima, Formação Rio do Sul e Formação Rio Bonito, Bacia do Paraná.

\footnotetext{
${ }^{1}$ Universidade Federal do Paraná, Department of Geology, Laboratory for Research in Applied Geophysics, R. Francisco Heráclito dos Santos, 100, Building VI, 81531-980, P.0. Box 19045, Curitiba, PR, Brazil - E-mails: herlonhr@gmail.com, francisco.ferreira@ufpr.br

${ }^{2}$ Universidade Federal de Santa Catarina, Department of Geoscience, Sedimentary Basin and Reservoir Characterization Research Group. Cidade Universitária Reitor João David Ferreira Lima, Florianópolis, SC, Brazil -E-mail: marivaldo.nascimento@ufsc.br
} 


\section{INTRODUCTION}

The sedimentary stratigraphic record suggests that glaciations have occurred episodically throughout the earth's history (Crowell, 1999). One of those glaciations affected the Gondwana Supercontinent during the Late Paleozoic and constituted the longest period of continuous glaciation in the Phanerozoic (Eyles et al., 2003). Carboniferous to Early Permian glaciogenic sedimentary rocks have been identified on all subcontinents of Gondwana, such as, South America (Buatois \& Mángano, 1995; López-Gamundí, 1997; Archanjo et al., 2006), Africa (Scheffler et al., 2003), Australia (Scheffler et al., 2003), and Antarctica (Collinson et al., 1994; Isbell et al., 2003). This glacial age is subdivided into three episodes (López-Gamundí, 1997): glacial episode I (Late Devonian-Earliest Carboniferous), glacial episode II (Late Carboniferous), and glacial episode III (Late Carboniferous-Early Permian) (Fig. 1A).

Sedimentological and stratigraphic studies of Permo-Carboniferous sedimentary rocks in the Paraná Basin (Fig. 1B) have suggested a transition of the glacial period to the subsequent global warming that controlled the deep paleoenvironmental change caused by transgression-regression of the Panthalassa at the western edge of the Gondwana Supercontinent (Medeiros \& Thomaz Filho, 1973; Milani, 1997; Vesely \& Assine, 2004; Carneiro \& da Costa, 2006; d'Ávila, 2009; Zielinski \& Nascimento, 2015). Climate change during late deposition of the Rio do Sul Formation (Itararé Group) and early deposition of the Rio Bonito Formation (Guatá Group) has been insufficiently studied. Most of the studies on climate records in the Itararé and Guatá Groups (Figs. 1B and 1C) were based on paleoenvironmental and stratigraphic data (Goldberg, 2001; Holz \& Kalkreuth, 2004; Slonski, 2002; Cacela, 2008).

This work presents gamma-ray spectrometric patterns of $\mathrm{eTh} / \mathrm{K}$, eTh/U ratios and clay minerals to investigate the paleoclimatic signature during the late sedimentation of the Taciba/Rio do Sul Formation and the early sedimentation of the Rio Bonito Formation in the eastern portion of the Paraná Basin (Fig. 1C). Gamma-ray spectrometric data reveal important information on paleoclimatic changes (Ruffell \& Worden, 2000), and petrographic data may reveal sedimentary provenance in different tectonic environments (Dickinson, 1985).

\section{METHODOLOGY}

\section{Geological setting and stratigraphy}

The Paraná Basin is located in the southwestern region of the South American continent and has an area of approximately
1,500,000 $\mathrm{km}^{2}$ (Bortoluzzi et al., 1987), Figure 1B. The origin of the Paraná Basin is related to the tectonic processes at the end of the Brasiliano Cycle, which controlled the exposure and expressive erosion of the continental crust and deposition of widespread sedimentary sequences (Zalán et al., 1987). The stratigraphic framework of the Paraná Basin comprises six supersequences more than 5,000 m thick (Zalán et al., 1987; Milani, 1997; Milani et al., 2007). The Gondwana I Supersequence comprises the Itararé, Guatá and Passa Dois groups (Fig. 2), represents the largest sedimentary volume of this basin (approximately 2,500 m thick), and overlies the Paraná Sequence and a 70 Ma hiatus caused by the development of ice caps on the Gondwana Supercontinent (Milani et al., 2007).

The glaciogenic sedimentary successions of the Itararé Group include sandstones, diamictites, black shales, and carbonates. Previous studies indicate that these rocks represent continental glacial and proglacial sedimentation (Leinz, 1937). The Itararé Group encompasses the lowermost sedimentary successions of the Gondwana I Supersequence, comprising the Lagoa Azul, Aquidauana, Campo Mourão and Taciba Formations (França \& Potter, 1988), Figure 2C. The Guatá Group rests on the glaciogenic deposits of the Itararé Group, a deglaciation sequence formed during the Permian Transgression (Lavina \& Lopes, 1987; Milani et al., 2007). This group includes the Rio Bonito Formation, consisting of greenish-gray, bioturbated siltstones and fine- to coarse-grained sandstones with coal layers and carbonaceous shales, and the fine- to medium-grained sandstones of the Palermo Formation (Bortoluzzi et al., 1987).

The Rio do Sul Formation (Itararé Group) comprises a $350 \mathrm{~m}$ thick sequence of dark, fine-grained sandstones, black shale and siltstones (informally known as Lontras Shales), as well as siltstones, diamictites, rhythmites and fine-grained sandstones that display wave ripples and flaser bedding in the upper part of the succession (Schneider et al., 1974). The Rio do Sul Formation includes the Rio Segredo, Chapéu do Sol and Rio do Sul Members (Bortoluzzi et al., 1987; França \& Potter, 1988). The Rio Segredo Member comprises graded to massive claystone and turbidite sandstones. Some evidence of shallow water, such as wave ripples, have been record in cores from the northern part of the basin. The Chapéu do Sol Member consists of massive to stratified diamictites, interpreted as rain-out deposits (mudstones with ice-rafted clasts), locally modified by resedimentation processes. The diamictites are dark gray, clay-rich sandstones with graded or intercalated very fine-grained sandstones succeeded by black shales, varvites, 

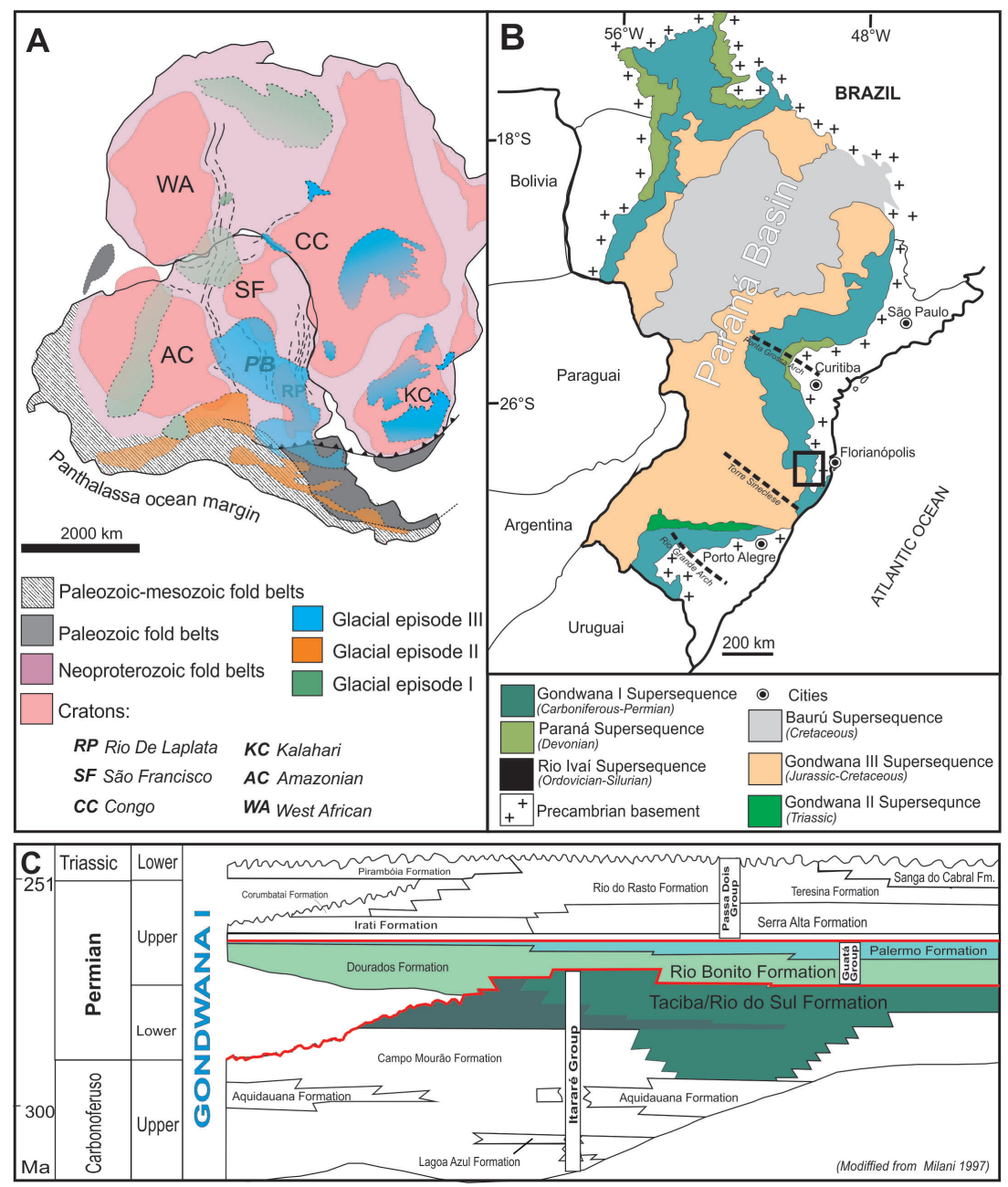

Figure 1 - (A) Western Gondwana with glacial episodes (Powell \& Li, 1994; Isbell et al., 2003; Lawver et al., 2011), with location of the Paraná Basin (PB); (B) Simplified geological map of the Paraná Basin with location of studied outcrops; (C) Chronostratigraphic chart of the Gondwana I Supersequence, showing the position of the studied stratigraphic, adapted from interval (Milani, 1997).

and dark gray to reddish siltstones (Bortoluzzi et al., 1987). In the southern part of the basin, these diamictites interfinger with dropstone-rich marine shales of the Rio do Sul Member. In the study area, the Taciba Formation rests directly on rocks of the Dom Feliciano Belt (Bortoluzzi et al., 1987; Menezes \& Nascimento, 2015).

The Rio Bonito Formation (Guatá Group) comprises fluvial to deltaic sandstones and shales, as well as coal layers (Medeiros \& Thomaz Filho, 1973). This formation represents a depositional cycle from the base to the top that encompasses the Triunfo, Paraguaçu and Siderópolis Members (Schneider et al., 1974; Milani et al., 2007). The Triunfo Member is composed of medium- to coarse-grained micaceous and poorly sorted sandstone, very fine-grained sandstone, and coal layers, as well as intraformational conglomerate (Bortoluzzi et al., 1987). The lower contact with the Taciba Formation is concordant, sometimes resting directly on the Precambrian basement. The Rio Bonito Formation marks the beginning of a deltaic development on the continental shelf and slope. The Paraguaçú Member includes intraformational pellets, sandstone and conglomerate, dark gray, medium gray or greenish-gray clayey carbonate layers, and transgressive layers of coal and overlies the fluvial-delta deposits of the Triunfo Member. The lower and upper contacts with the Triunfo Member and Siderópolis Member are concordant. The Siderópolis Member comprises dark gray fine sandstone, interlayered gray siltstone, carbonaceous siltstone, and charcoal 


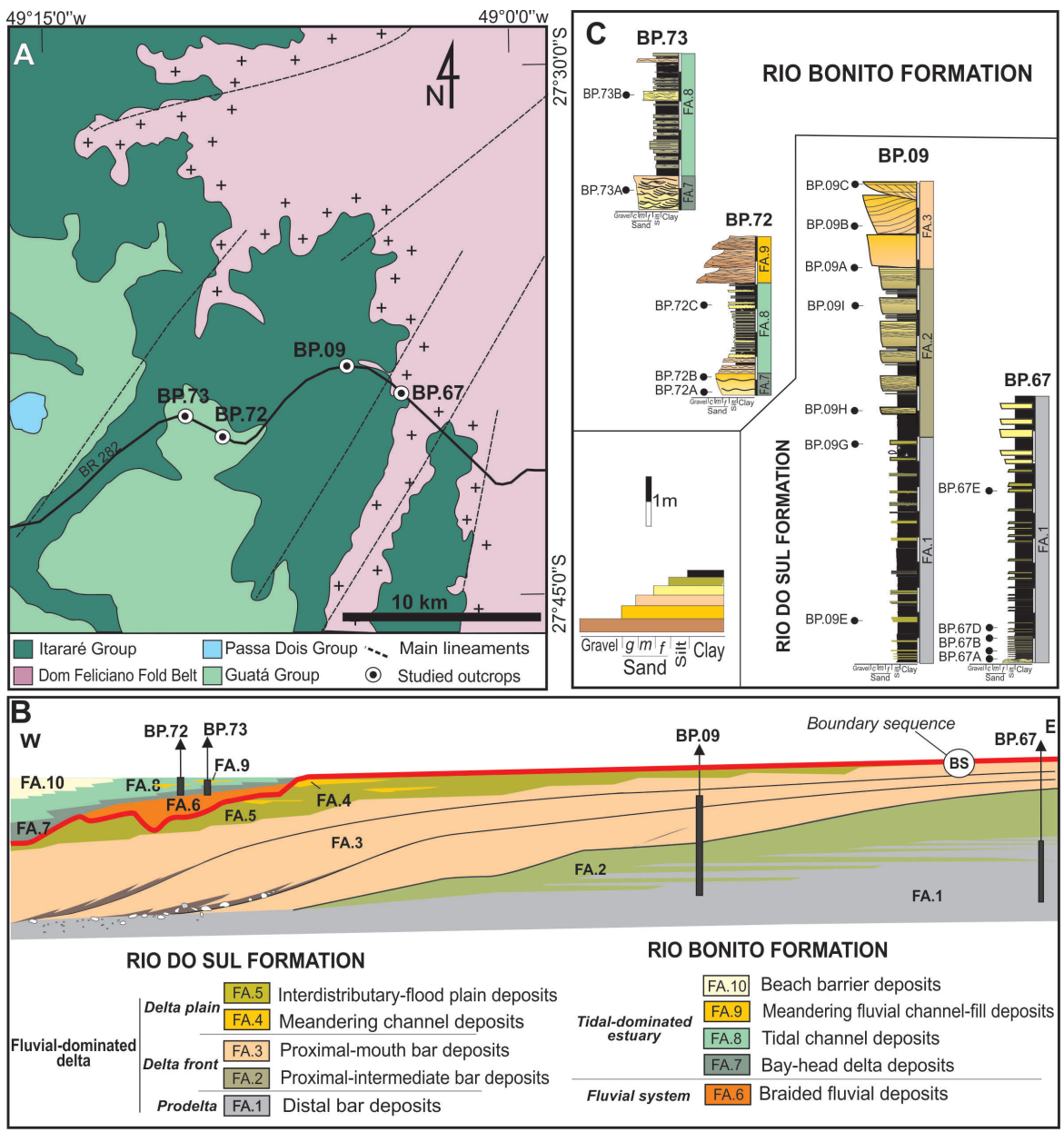

Figure 2 - (A) Geological map of the study area in the Rancho Queimado region, with location of outcrops; (B) Schematic stratigraphic section demonstrating the main facies association relationships and related paleoenvironments; (C) Logged sections of the outcrops with position of the analyzed samples.

bed and includes sandy-packages in the most important coal layers of the basin (Bortoluzzi et al., 1987).

\section{Laboratory Measurements}

The stratigraphic sections of the Rio do Sul and Rio Bonito Formations were examined and logged at four localities of the Rancho Queimado region (Fig. 2). The exposures were at road cuttings along the BR-282 (Fig. 2A). The study outcrops have a wide lateral $(>30 \mathrm{~m}$ ) and vertical (5 to $15 \mathrm{~m}$ ) exposure and include the uppermost portion of the Rio do Sul Formation (BP09 and BP67) and the lowermost portion of the Rio Bonito Formation (BP72 and BP73) in this region. Four stratigraphic sections on the studied outcrops (BP67, BP09, BP72 and BP73; Fig. 2) were made.
Twelve sandstone thin sections from the Rio do Sul Formation and seven thin sections from the Rio Bonito Formation were analyzed under an optical microscope at the Sedimentary Basin Laboratory (LABAC/UFSC). The diagenetic constituents and clay minerals were studied using a scanning electron microscope (JEOL JSM 6010LA) at both the Central Laboratory of Scanning Electron Microscopy (LCME/UFSC) and Laboratory of Minerals and Rocks (LAMIR/UFPR). Four samples of shales were taken from each formation to analyze clay mineral associations using X-ray diffraction (XRD) on a PANalytical model X'PertPRO-MPD (LAMIR/UFPR) equipped with a vertical goniometer of $240 \mathrm{~mm}$ and a linear detector with a 2,122 ${ }^{\circ}$ opening (Xcelerator).

The spectral gamma-ray signatures were obtained using the RS-230 portable radioscope (Radiation Solutions, Canada) from 

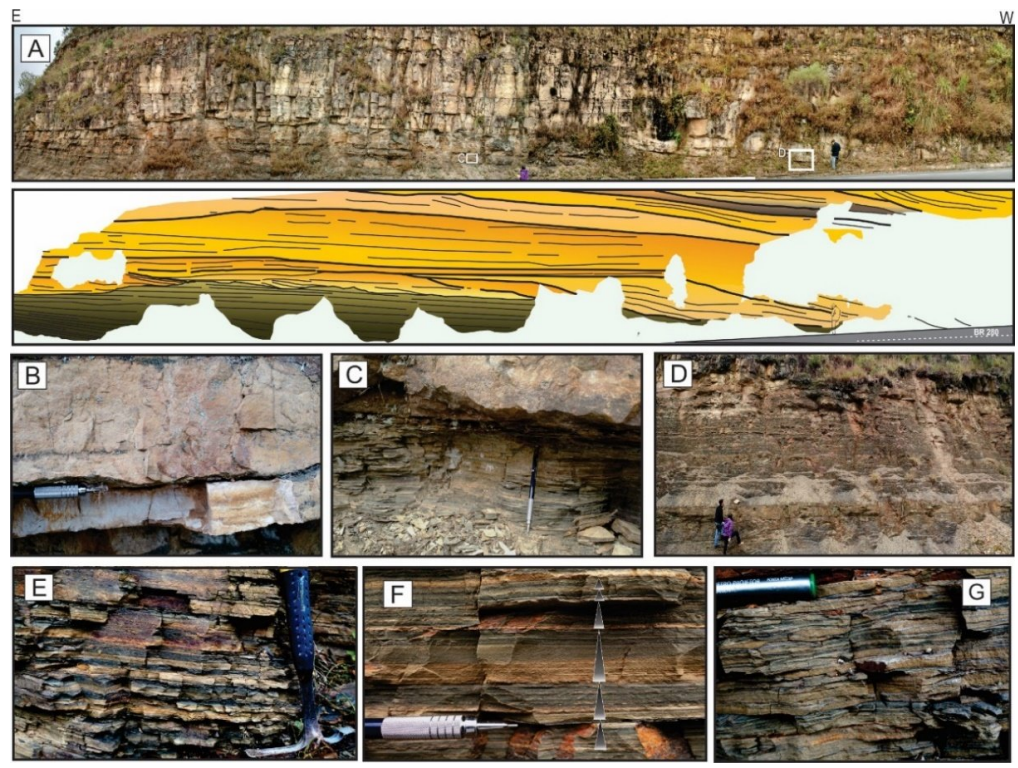

Figure 3 - Facies and depositional architecture of the Rio do Sul Formation (BP.67 and BP.09): (A) panoramic view of the delta-front deposits and prodelta deposits; (B) sandstone of the mouth bar deposits; (C) contact between mouth bar and prodelta deposits; (D) a panoramic view of the prodelta deposits; and (E-G) fining-upward cycles in the lowermost portion of the prodelta deposits.
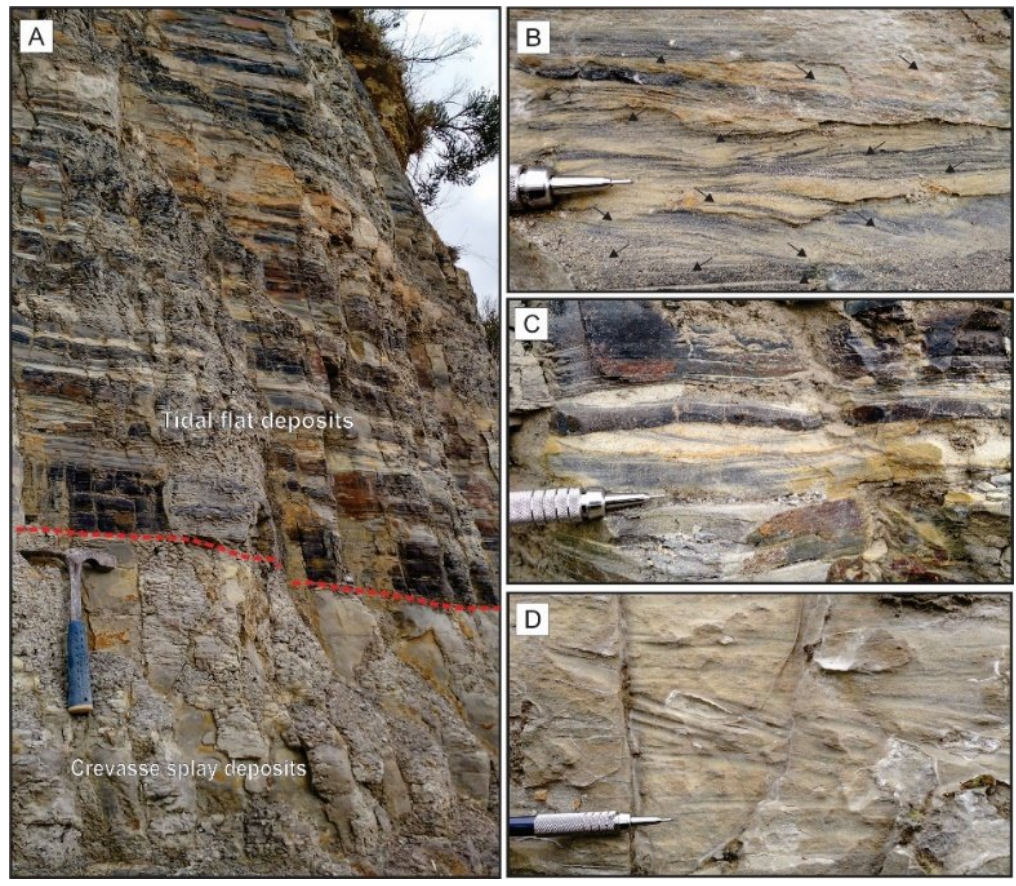

Figure 4 - Sedimentary facies of the Rio Bonito Formation (outcrop BP.73): (A) crevasse splay deposits in tidal flat environment; (B) cross lamination (arrows) with mud drapes, and plane parallel lamination; (C) details of wavy bed and cross lamination structures with mud drapes; and (D) detail of low-angle cross lamination and undulated lamination in crevasse splay deposits. 

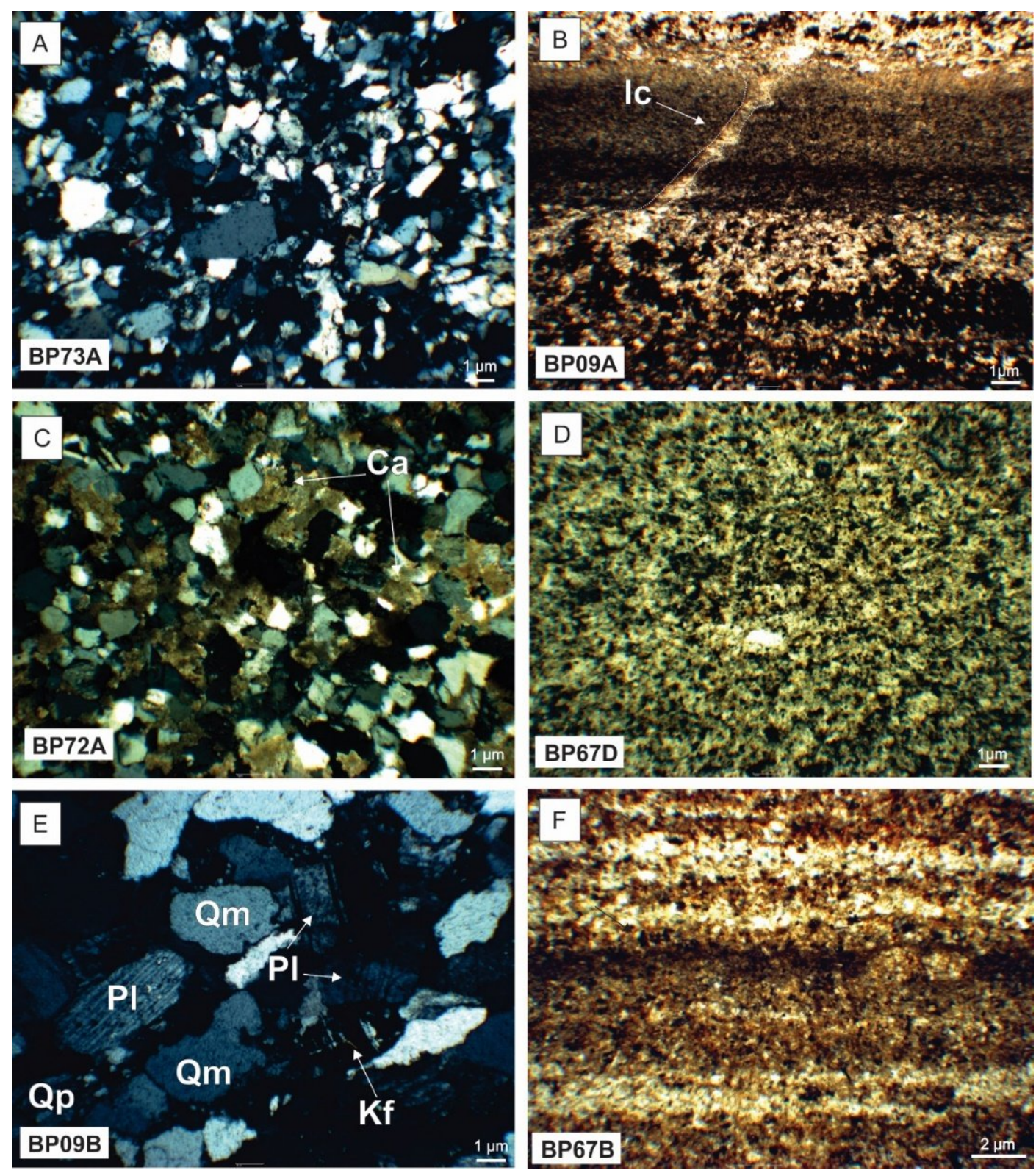

Figure 5 - Micrography under plane-polarized light (PPL) and crossed-polarized light (XPL) of sandstones of the Rio do Sul and Rio Bonito Formations: (A) XPL micrograph of fine-grained, quartz-rich monocrystalline quartz sandstone; (B) PPL micrograph of laminated rhythmite showing ichnofossils (IC); (C) XPL micrograph of fine-grained, quartz-rich sandstone of the Rio Bonito Formations with carbonate cement (Ca); (D) PPL micrograph of massive siltstone; (E) XPL micrograph arkose with quartz, plagioclase (PI), and K-feldspar (Kf) grains with concave-convex- to sutured contacts; and (F) PPL micrography of laminated fine-grained siltstone.

the Laboratory for Research in Applied Geophysics (LPGA) at UFPR. The equipment has a detector with a bismuth germanium oxide (BG0) crystal with $6.3 \mathrm{in}^{3}\left(103 \mathrm{~cm}^{3}\right)$ sensitivity. The readings were obtained in counts per minute (cpm) for each element and total count (TC) in parts per million (ppm) for uranium (eU), \% for potassium (K) and ppm for uranium $\left({ }^{238} \mathrm{U}\right)$ and thorium $\left({ }^{232} \mathrm{Th}\right)$. The data were acquired with spacing of $10 \mathrm{~cm}$ (sensor diameter) and an integration time of $120 \mathrm{~s}$. The readings were performed with the apparatus positioned perpendicular to the surface of the strata. The measured data were 
stored in the apparatus and transferred to a computer for analysis using RS-Analyst software.

\section{RESULTS}

In the study area, the Rio do Sul Formation comprises a fluvial-glacial delta system composed of a siltite and fine-grained sandstone succession (prodelta deposits at the base), which grades to a medium- to coarse-grained sandstone succession (delta front deposits at the top) (Fig. 3A). The prodelta deposits include tabular rhythmite (siltite and fine-grained sandstone) with plane-parallel lamination, massive and tabular medium- to fine-grained sandstone, fine-grained sandstone with symmetrical ripples, tabular and massive shales, very fine-grained sandstone with symmetrical lamination, and laminated shales (Figs. 3D, E, F and $\mathrm{G}$ ). The delta front deposits (Fig. 3B) encompass moderately sorted sandstones with tangential cross stratification, low-angle cross stratification, tabular cross stratification, symmetrical ripples, and asymmetrical cross laminations. The contact between these deposits is considered a basal surface of forced regression (Figs. 3B and C). It occurs during stages of sea level fall when the shoreline is forced to regress by the falling base sea level irrespective of sediment supply.

In the study area, the Rio Bonito Formation comprises 1) a braided fluvial system at the base and 2) an estuarine-lagoon delta at the top. The braided fluvial deposits (Triunfo Member) rest directly on the Rio Bonito Formation and are limited at the base by a sequence boundary (SB) and at the top by a transgressive surface (TS). It is $20 \mathrm{~m}$ thick and laterally extends to $30 \mathrm{~m}$ of coarse-grained, massive and stratified sandstones. The estuarine delta consists of a sequence of bay delta, central bay fill, estuarine channel and tide bars to delta deposits and composes a succession approximately $15 \mathrm{~m}$ thick by $250 \mathrm{~m}$ wide (Fig. 10). This estuarine sequence presents considerable facies variability, marked at the base by an intercalation of fine-grained sandstone and heterolithic central bay fill deposits. It is succeeded by a fine-grained sandstone and by fine-grained intraformational conglomerates from the tidal channel (Fig. 4).

\section{Mineral compositions}

The Rio do Sul Formation includes medium- to very-fine-grained sandstone consisting of angular to subangular monocrystalline quartz with straight extinction and polycrystalline quartz. The plagioclase has a prismatic tabular form and exhibits albite Carlsbad twinning. The framework grains exhibit concave-convex to sutured contacts (Fig. 5E). The matrix usually represents less than $5 \%$ of the volume of the rock and includes monocrystalline quartz and mica. The feldspar grains exhibit albite overgrowth and intra-stratal dissolution. The muscovite shows mechanical deformation. Syntaxial overgrowth silica cement is abundant, and carbonate cement occurs due to grain replacement. Vermiculite occurs in only the uppermost portion of this succession and is in booklet form (Fig. 6).

The sandstones of the Rio Bonito Formation are thin- to medium-grained, well to poorly sorted, with quartz, feldspar and lithic angular grains. Point, long, sutured and concave-convex contacts occur (Fig. 5). Monocrystalline quartz presents anhedral angular to subangular form, with straight to undulating extinction. Polycrystalline quartz generally displays subrounded to rounded shapes. Microcline, orthoclase and plagioclase grains are angular in form, and present polysynthetic and Carlsbad twins, and alteration to kaolinite. Metamorphic and pelite fragments sometimes occur as pseudomatrix. The diagenetic features include mechanical infiltration of clay, iron oxide films, grain crushing, concave-convex to sutured contacts, silica overgrowth cement, carbonate cement, replacement of feldspar to kaolinite, cement dissolution and iron oxide-hydroxide precipitation in secondary porosity.

\section{Clay mineral assemblage}

The clay minerals in the Rio do Sul and Rio Bonito Formations include illite, vermiculite, and interlayered illite-smectite and chlorite (Figs. 6 and 7). The illite was identified by reflections at $10 \AA$. The vermiculite was identified by reflections at $4.3 \AA$. Octahedral smectite and quartz traces occur. The illite occurs in all samples of the Rio do Sul Member and was not identified in the Rio Bonito Formation (Fig. 7). The illite-smectite interlayers generally occur with associated illite crystals. Illite $\left(\mathrm{K}_{1-1.5} \mathrm{Al}_{4}\left[\mathrm{Si}_{7-6.5} \mathrm{Al}_{1.1 .5} \mathrm{O}_{20}\right](\mathrm{OH})_{8}\right)$ is the main clay mineral in the Rio do Sul Formation, constituting 50 to $60 \%$ of the assemblage, and SEM micrographs show dioctahedral-trioctahedral illite (Fig. 6).

Vermiculite $\quad\left(\begin{array}{lllll}\mathrm{Mg}_{3} & \left(\mathrm{Si}_{3} \mathrm{Al}\right) & \mathrm{O}_{10}(\mathrm{OH})_{2} & \mathrm{Mg}_{0.5} & \left(\mathrm{H}_{2} \mathrm{O}_{4}\right)_{4}\end{array}\right)$ constitutes $20 \%$ of the clay mineral assemblage in the middle to upper portions of the Rio do Sul Formation. Illite-smectite interlayers represent approximately $1 \%$ of the assemblage. Chlorite ((Mg, Al, $\left.\mathrm{Fe})_{12}\left[(\mathrm{Si}, \mathrm{Al})_{8} \mathrm{O}_{20}\right](\mathrm{OH})_{16}\right)$ was found in only the Rio Bonito Formation (Fig. 7: BP73). 

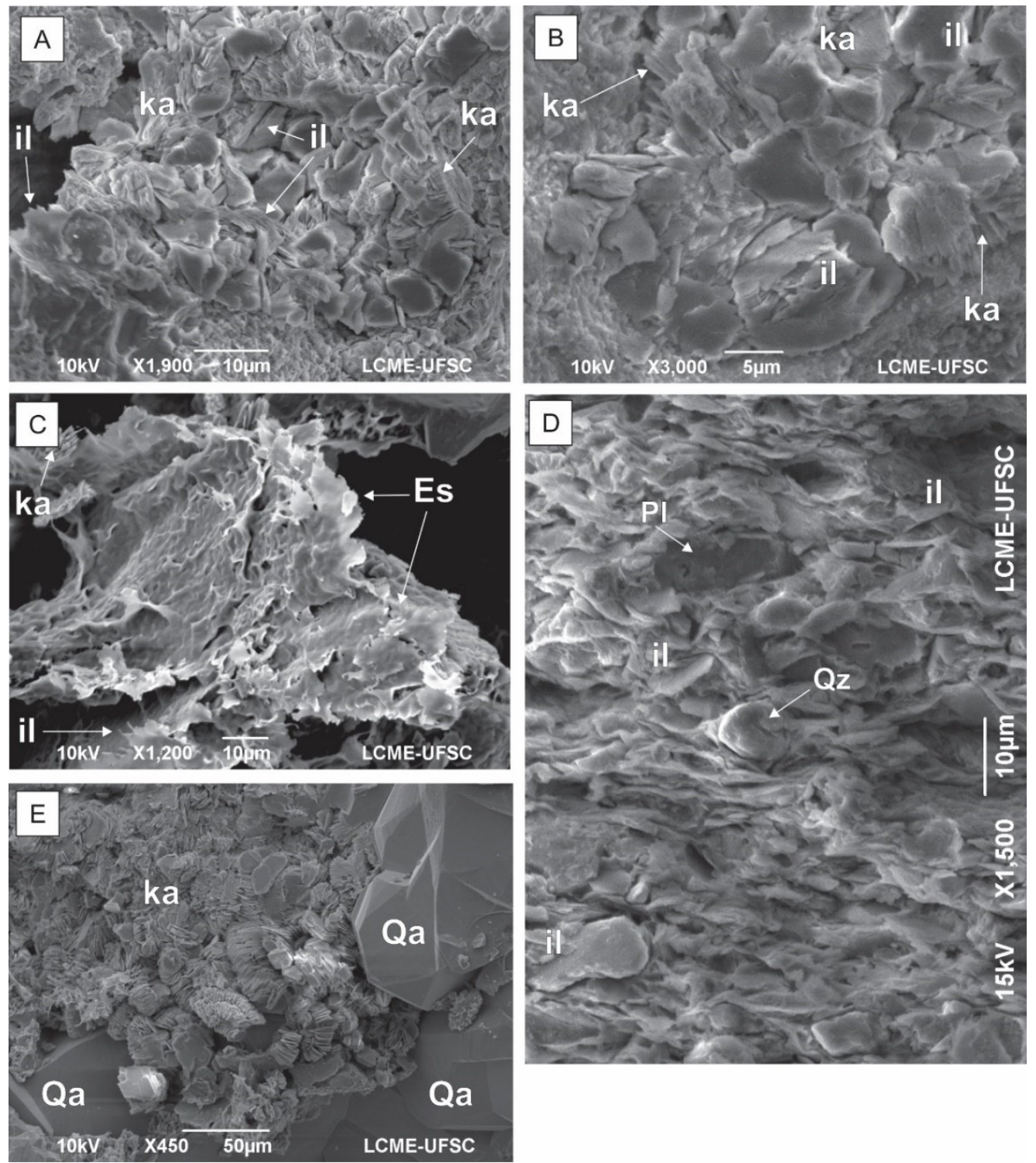

Figure 6 - SEM micrography of the Rio do Sul and Rio Bonito Formations: (A-B) illite (il), quartz grains (Qz) and booklet kaolinite (ka) in sandstones; (C) smectite and illite; (D) illite parallel to the lamination, contouring the silty-quartz (Qz) and plagioclase (PI); and (E) booklet kaolinite and authigenic quartz (Qa).

\section{Gamma-ray signature from the Rio do Sul Formation}

Gamma-ray spectrometry is a valuable technique to combine with fieldwork to recognize the effect of climatic control on sedimentation. The eU, eTh and $\mathrm{K}$ patterns and $\mathrm{eTh} / \mathrm{K}$ and $\mathrm{eTh} / \mathrm{eU}$ ratios in the Rio do Sul Formation were interpreted in two profiles, as shown in Figure 8A. Correlation coefficients for $\mathrm{K}$, eU and eTh against counts per minute (cpm) were produced to verify the calibration of the gamma spectrometer. TC concentrations, K (\%), eU (ppm) and eTh (ppm) are listed in Table 1.
Spectral gamma-ray logs of the sandstones have lower $\mathrm{K}$ concentrations (BP09 top), ranging from 1.2 to $2.4 \%$. In contrast, eU presents values approximately 17.9 ppm, having a minimum value of $7.1 \mathrm{ppm}$, and eTh presents the highest value in this lithofacies (31 to $45.9 \mathrm{ppm}$ ). The eU and eTh have values of 14 and $40 \mathrm{ppm}$, respectively. In these two lithofacies, TC values show direct correlation with eU and eTh concentrations.

The shales show decrease in K-concentrations toward the top of the profile BP.67. In profile BP.09, these concentrations are 

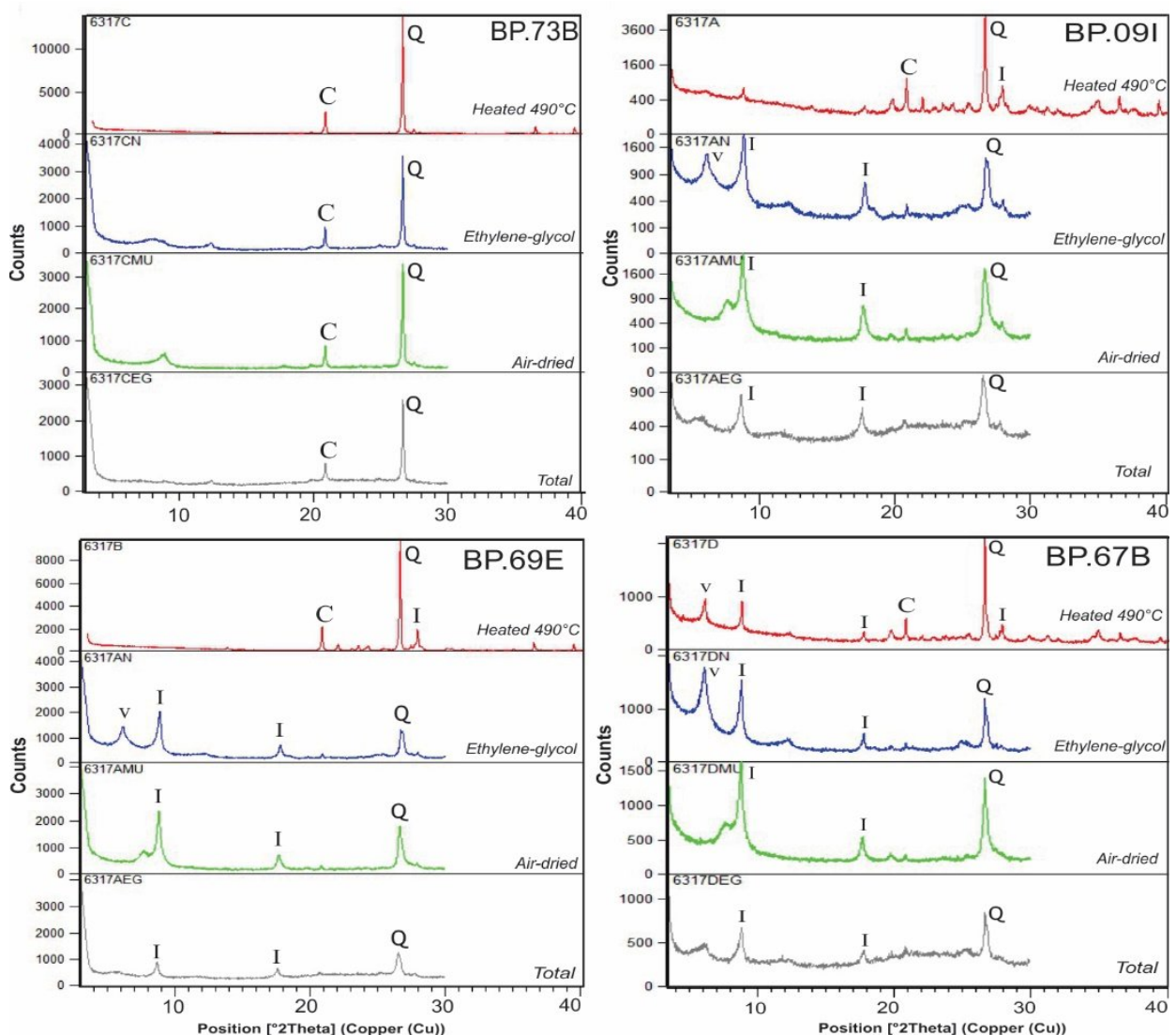

Figure 7 - XRD traces of main clay minerals (air-dry, ethylene glycol-solvated and heated to $450^{\circ} \mathrm{C}$ ) of the Rio do Sul and Rio Bonito Formations. Illite (I), vermiculite (v), quartz (Q) and chlorite (C).

Table 1 - Spectral gamma-ray data from sandstone and shale of the Rio do Sul and Rio Bonito Formation.

\begin{tabular}{|c|c|c|}
\hline Rio do Sul Formation & Sandstones (16 samples) & Shales (153 samples) \\
\hline Elements & $\mathrm{TC}(\mathrm{ppm}) \mathrm{K}(\%) \mathrm{eU}(\mathrm{ppm})$ eTh(ppm) & $\mathrm{TC}(\mathrm{ppm}) \mathrm{K}(\%)$ eU(ppm) eTh(ppm) \\
\hline Mean & 2240.821 .609 .7738 .65 & 1855.873 .706 .0224 .80 \\
\hline Standard deviation & 248.820 .302 .623 .32 & 249.530 .401 .553 .75 \\
\hline Variation coefficient & 0.111 .180 .260 .08 & 0.130 .100 .250 .15 \\
\hline Maximum & 2945.202 .4017 .9045 .90 & 3302.204 .9014 .3048 .30 \\
\hline Minimum & 1919.701 .207 .1031 .30 & 1532.502 .103 .6019 .20 \\
\hline Rio Bonito Formation & Sandstones (38 samples) & Shales (63 samples) \\
\hline Elements & TC(ppm) K(\%) eU(ppm) eTh(ppm) & TC(ppm) K(\%) eU(ppm) eTh(ppm) \\
\hline Mean & 1693.011 .8410 .7019 .90 & 1677.073 .067 .7019 .50 \\
\hline Standard deviation & 681.600 .408 .006 .00 & 336.290 .633 .102 .30 \\
\hline Variation coefficient & 0.400 .210 .740 .30 & 0.200 .200 .400 .11 \\
\hline Maximum & 3166.002 .6028 .6030 .90 & 2177.304 .2014 .7023 .50 \\
\hline Minimum & 923.301 .202 .3011 .50 & 1140.001 .803 .0014 .20 \\
\hline
\end{tabular}


inverse and increase to the top (Fig. 8). In these lithofacies, the values range between $2.1 \%$ and $4.9 \%$ (Table 1). The eU and eTh show values between 3.6 and 14.3 ppm and between 19.2 and $48.3 \mathrm{ppm}$, respectively. In general, this result indicates that the concentrations of these radionuclides present a gradual increase from the base (BP.09) to the top (BP.67) of the session. The TC curves are similar to the curves of $\mathrm{K}$, eU and eTh, showing the relationship with these three elements.

The character of the gamma-ray log through the investigated sections shows an upward increase in the concentrations of these radionuclides, illustrating consistency with TC data. However, there is no significant variation in the eTh/K and eTh/eU ratios since growth is equivalent to the $\mathrm{K}$, $\mathrm{eU}$ and eTh concentrations. The $\mathrm{K}$ has a small decrease in concentration, as observed at the top of profile BP67 to the base of profile BP09. Toward the top, the $K$ values increase again and equate with the values measured at the base of profile BP09, which corresponds to the base of the investigated session. The other radionuclides show gradual growth from the base to the top of the session, as already mentioned. The eTh/K and eTh/eU ratios from bottom to top of the session show low and relatively homogeneous values (7 for eTh/K, 2 and 8 for eTh/eU). However, the sandstones at the top of profile BP.09 have a considerable increase in $\mathrm{eTh} / \mathrm{K}$ ratios, remaining relatively constant (2 to 6) compared to the eTh/eU ratios.

\section{Spectral gamma-ray signature from the Rio Bonito Formation}

Two gamma-ray profiles were measured in the Rio Bonito Formation (Fig. 9), and data from each lithofacies, including TC, K, eU and eTh concentrations, are listed in Table 01. In the sandstones at the base and top portions of this stratigraphic unit (BP73 and BP72), the $K$ values range from 1.2 to $2.6 \%$, and the $\mathrm{eU}$ signatures have values from 2.3 to $28.6 \mathrm{ppm}$. In the log from $\mathrm{BP72}$, the eU values range from 1.5 to $5 \mathrm{ppm}$, with a progressive increase upward. The sandstones at the base of the BP73 profile produce eTh values that gradually increase toward the top of the section. In contrast, the sandstones at the base of the log from BP72 show values ranging from 12 to $17 \mathrm{ppm}$ from the bottom to the top. The CT data are similar to curves of eU and eTh, indicating the influence of these radionuclides on the CT values.

The pelites of the Rio Bonito Formation exhibit $\mathrm{K}$ contents from 1.8 to $4.2 \%$ (in the lower portion of the BP73 profile) and from 2.6 to $3.2 \%$ (in the upper portion of the BP72 profile). The eU measurements are similar to the $\mathrm{K}$ measurements, with $14.7 \mathrm{ppm}$ at the base to $3.0 \mathrm{ppm}$ in the upper portion of the section. At the base of the secession, the eTh values range from 14.2 to $23.5 \mathrm{ppm}$ and strongly correlate with eTh from the upper portion. The TC data have similar patterns to $\mathrm{K}$, eU and $\mathrm{eTh}$, indicating the influence of these radionuclide concentrations. The gamma-spectrophotometric data of the Rio Bonito Formation show a significant upward decrease in the radionuclides concentration, which is more evident in to TC data. Anomalous values of eU and eTh in the sandstones cause the displacement of the curves to the right, increasing the contrast with the $\mathrm{K}$ concentration. The shales present high- $\mathrm{K}$ concentrations with respect to $\mathrm{eU}$ and $\mathrm{eTh}$. The variations in the $\mathrm{eTh} / \mathrm{K}$ and $\mathrm{eTh} / \mathrm{eU}$ ratios are not expressive $(\sim 5)$, but with peaks at $\sim 7$. The increase in eTh/K ratios is noted mainly in the sandstones (14 to $25 \mathrm{ppm}$ ) but not accompanied by the eTh/eU ratios, which show a small decrease $(\sim 2)$ in relation to the general pattern $(\sim 2.5$ to 7$)$. The low eTh/eU ratio results from the relative increase in eU concentration in this sedimentary facies.

\section{DISCUSSION}

Clay minerals are a main product of weathering of primary minerals (feldspars and micas) or preexisting rock fragments (volcanics or shales). The clay mineral assemblage is a significant indicator of paleoclimatic regimes, paleotectonic processes and diagenetic processes. Detrital or authigenic clay minerals are widely used to determine the climatic conditions during sediment deposition (Parry \& Reeves, 1968; Singer, 1984; Chamley, 1989; Tucker, 2001; Gonçalves et al., 2006). The clay minerals identified in the Rio do Sul and Rio Bonito Formation include illite, vermiculite and mixed layer clay minerals (Fig. 7).

Illite is the main clay mineral in the Rio do Sul Formation and is ca. 50 to $60 \%$ of the assemblage, especially in the rhythmites and fine-grained sandstones. According to Velde (1995), the illite formation includes slow weathering processes, even in an environment with high-K availability. In the Rio do Sul Formation, the illite indicates provenance from Precambrian granitoid and metamorphic rocks (Dom Feliciano Belt), as well as older sedimentary rocks. The lack of occurrence of smectite in these formations suggests a detrital origin of the illite. According to Hower et al. (1976), a 5,000 $\mathrm{m}$ depth is required for $75 \%$ of the smectic layers of the clay fraction to transform into illite. However, Ibrahim (2008) considers that even under deep burial conditions, the illitization of the smectite is not intense. The rich $\mathrm{Na}^{+}-\mathrm{K}^{+}$ environments aid in the formation of mixed layers and micas. Vermiculite has a structure similar to smectite, although it is 


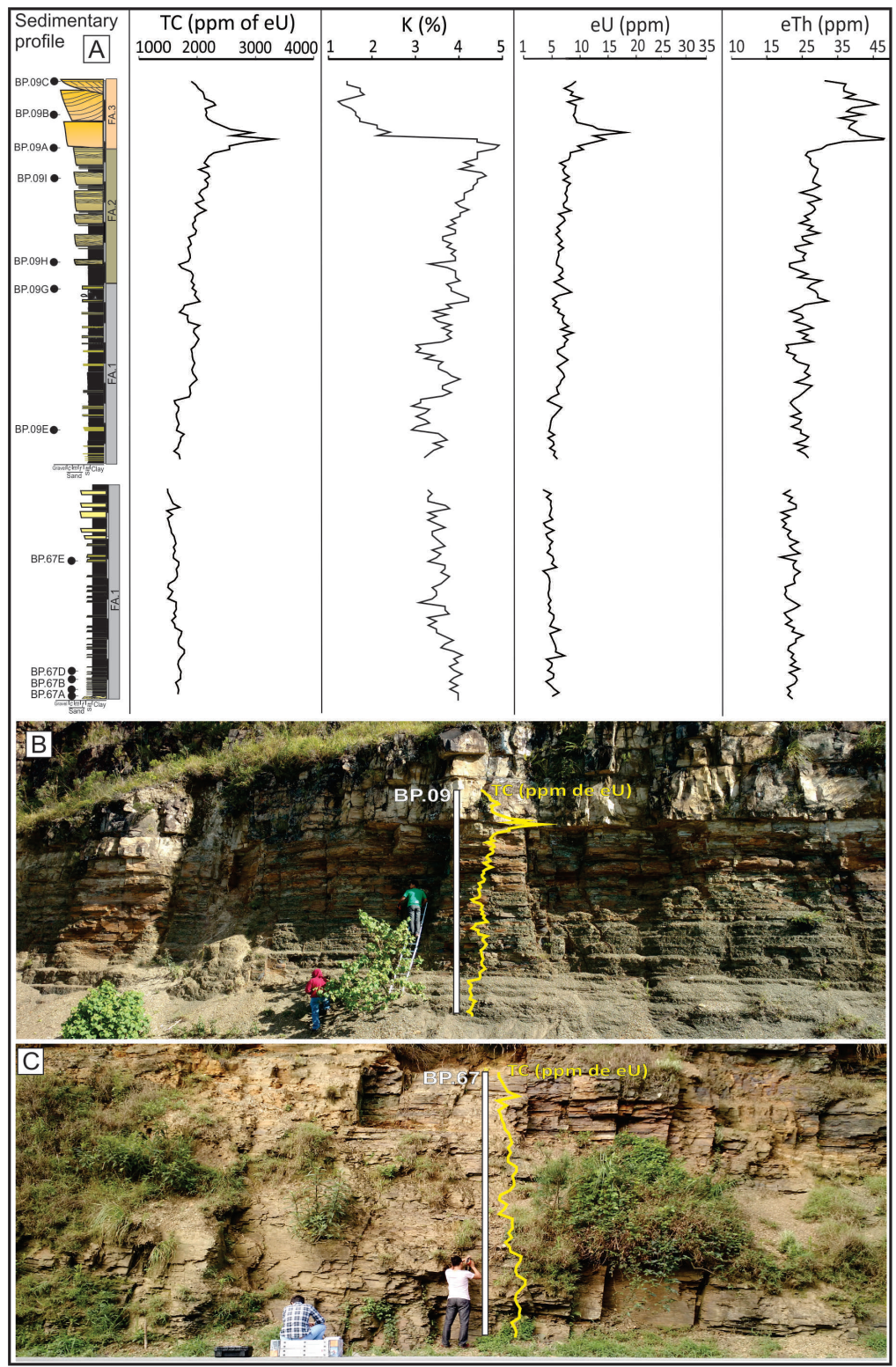

Figure 8 - (A) Sedimentary logs with facies associations (AF), including sample locations and gamma-ray signatures (TC, K, eU and eTh); and (B and C) Field photographs of the outcrops in the Rio do Sul Formation (BP09 and BP67, respectively).

less expandable (Tucker, 2001), indicating leaching of K-feldspar (Kf) during diagenesis or weathering of muscovite under good drainage and low-pH conditions that are very abundant in both fine-grained sandstone and rhythmites.

The detrital illite indicates deposition in cold weather, with a tendency toward warmer weather conditions. The depositional context of the Rio do Sul Formation in the studied area involves the movement of the Gondwana Supercontinent from the South Pole to the equatorial region, implying significant climatic and tectonic changes (Milani et al., 2007). In this paleogeographic context, temperatures progressively increased, favoring the formation of clay minerals in increasingly hot and humid climatic conditions, accompanied by transgressive processes (Fig. 10). In addition, Chemical Index Alteration (CIA: not yet published) from analyzed samples show low values ( 6 and 7.5), indicating minimal chemical weathering in the source area. 


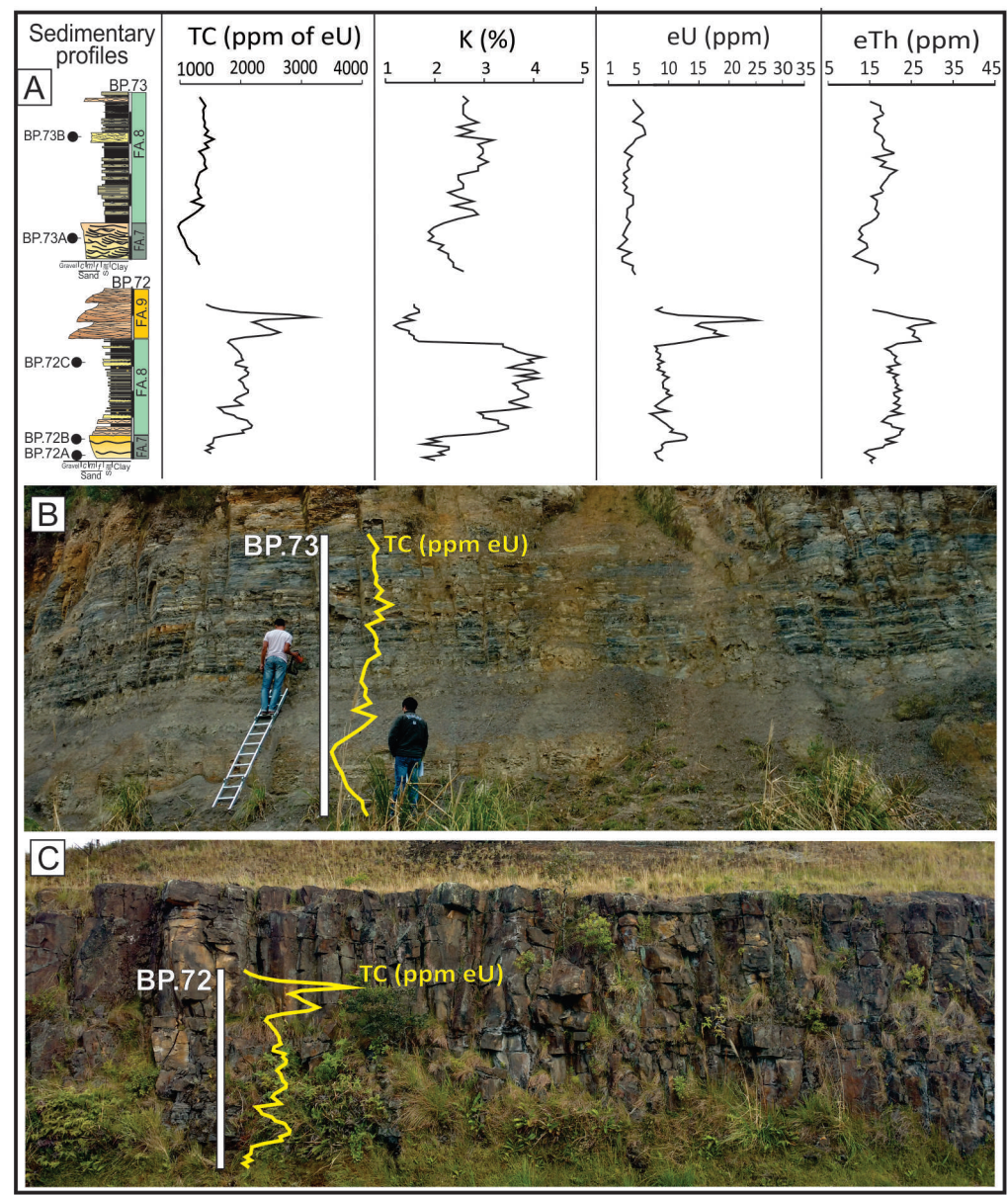

Figure 9 - (A) Sedimentary logs with facies associations (FA), sampled levels and gamma-ray data (TC, $\mathrm{K}$, eU and eTh) of the Rio Bonito Formation; and (B, C) Field photographs of the outcrops (BP72 and BP73).

The gamma-ray patterns from shales of the Rio do Sul Formation show low eTh/K (5 to 7) and eTh/eU (2 to 6 ) ratios from the base to the top of the studied profiles. However, in the sandstones at the top of the succession, the $\mathrm{eTh} / \mathrm{K}$ ratios are markedly high ( $>35$ ), indicating the influence of high $\mathrm{eU}$ and eTh concentrations. According to Ruffell \& Worden (2000), potassium is especially common in feldspars, micas and clay mineral. In contrast, uranium and thorium are common in clay minerals, feldspars, heavy minerals, phosphates, and organic matter. Although heavy minerals may contain uranium and thorium, the main factor controlling the presence of the radionuclides is their adsorption by organic matter and clays.

According to Menezes \& Nascimento (2015), the arkose sandstones of the sections studied have rich-feldspar and mica matrix. Therefore, these mineralogical features can influence the
$\mathrm{K}, \mathrm{eU}$ and eTh concentrations in shales. Anomalous values of $\mathrm{K}$, $\mathrm{eU}$ and $\mathrm{eTh}$ recorded in the sandstones (above) and shales (at the base) interface (see Fig. 10), resulting from the leaching of these radionuclides from the upper strata, which tend to concentrate at the interface of the shales. Shales exhibit high eTh/K and eTh/eU ratios because they have low permeability, which limits the intra-stratal dissolution and allows the preservation of these elements (Schnyder et al., 2006). Thus, the eTh/K and eTh/eU ratios from shales can be used as paleoclimatic indicators (Ruffell \& Worden, 2000).

Although eTh/K and eTh/eU ratios from the base $(<5)$ to the top ( $>7)$ of the Rio do Sul Formation indicate a tendency toward arid to cold conditions, it is considered that the progressive increase in these ratios could also indicate a gradual increase in temperature, favoring the remobilization of potassium, uranium, 


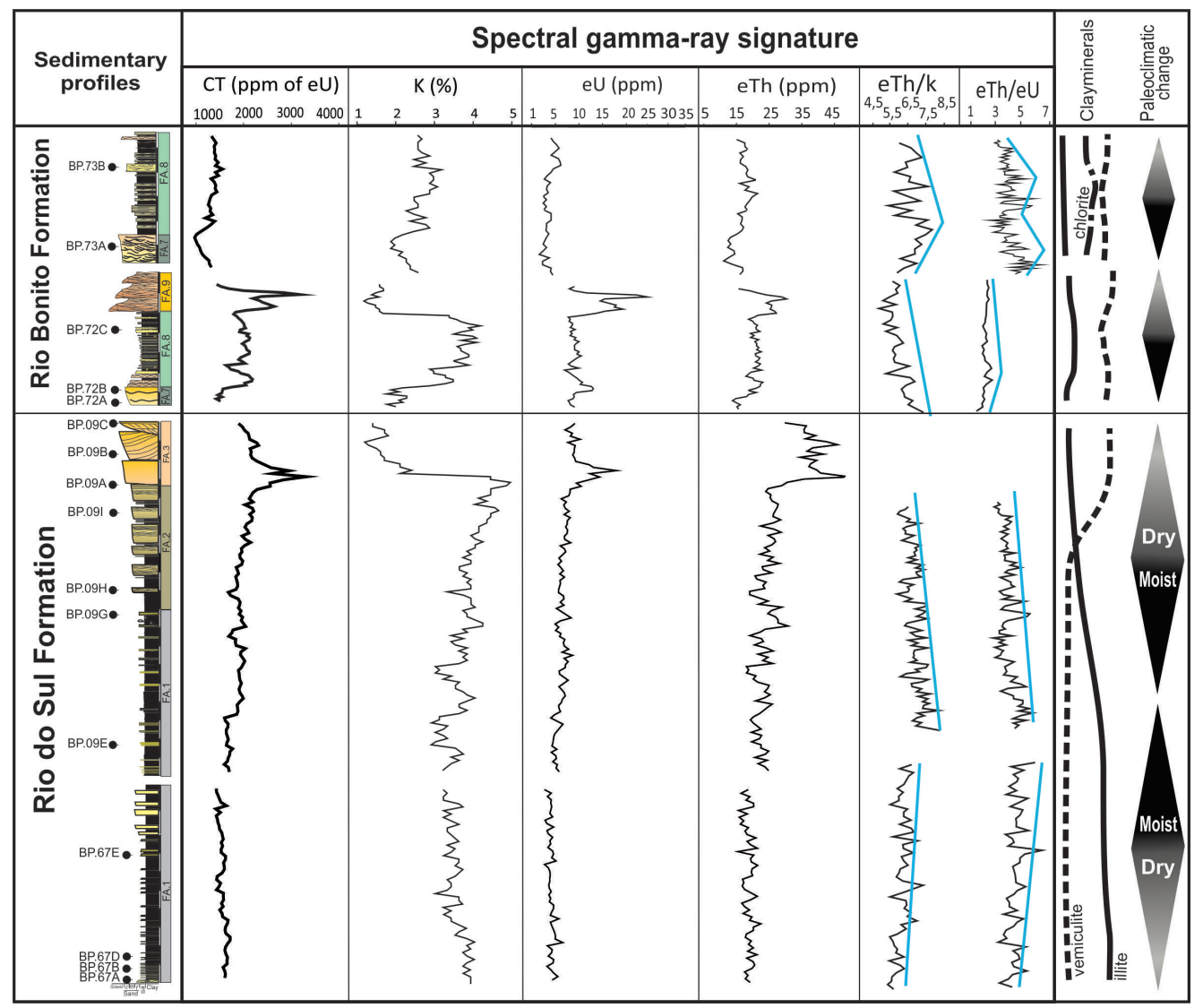

Figure 10 - Paleoclimatic interpretation of the Rio do Sul Member and Rio Bonito Formation from gamma-ray spectrometry and clay minerals mineralogy.

and thorium concentrations. The eTh/K and eTh/eU ratios in the Rio Bonito Formation (6 to 7.3 at the base to ca. 5 at the top) indicate an increase and then decrease in temperature (Ruffell \& Worden, 2000). Low eTh/K and eTh/eU ratios indicate cooler weather conditions; thus, the ratios indicate that the temperatures became progressively hotter and wetter, alternated by cycles of aridization of the environment.

The high eTh/K ratios (ca. 25) recorded in the lower portion of the Rio Bonito Formation are influenced by the adsorption capacity of the clays in the shales. According to Rider (1990), values above 3,000 ppm indicate high uranium and thorium content. In the Rio Bonito Formation, the anomalous values of the $\mathrm{eTh} / \mathrm{K}$ ratios are related to the coalbeds of this unit.

\section{CONCLUSIONS}

Clay mineralogy assemblages through the Rio do Sul and Rio Bonito formations indicates alternating moist and arid phases. The abrupt climate change toward a more arid environment is supported by the dataset of the present paper. This aridity coincides with a cold interval, suggesting a relationship between cold and arid conditions during the late Permian.

Changes in illite content are mirrored by $\mathrm{eTh} / \mathrm{K}$ ratios recorded in the spectral gamma-ray log. Vermiculite has no impact on the eTh/K ratios, allowing the spectral gamma-ray log to be used in conjunction with XRD analysis; for example, the XRD indication of high kaolinite/illite ratio combined with the low spectral gamma-ray eTh/K ratio.

The $e T h / K$ and $e T h / U$ ratios suggest an arid and cold climate during deposition of the base of the Taciba Formation, as indicated by detrital illite. The progressive increase in the eTh/K and eTh/U ratios toward the top indicates greater $\mathrm{K}$ and $\mathrm{eU}$ leaching with respect to eTh, suggesting more humid and hot climates.

The $e T h / K$ and $e T h / U$ ratios of the Rio Bonito Formation indicate a temperature increase toward the top of this formation. However, the oscillations in these ratios suggest momentary 
enrichment in $\mathrm{K}$ and eU with respect to eTh, which is also indicated by the variations in the $\mathrm{eTh} / \mathrm{K}$ and $\mathrm{eTh} / \mathrm{U}$ ratios.

The analysis of the clay minerals and the gamma radiation in the layers that mark the passage between the Rio do Sul and Rio Bonito formations allow us to investigate the paleoclimatic characteristics contemporaneous to the formation of these deposits in a paleogeographic context still little understood of the Evolution of the Paraná Basin.

\section{ACKNOWLEDGMENTS}

This study was supported by: 1) PFRH240-PB-UFSC; and 2) National Council for Scientific and Technological Development of Brazil (306978/2015-6). The authors are very grateful to Almério Barros França, Leonardo Cury and Valter Becegato for their expert and invaluable suggestions and assistance in the laboratory at LAMIR/UFPR, and to Itaipu Binacional for their support in the gamma spectrometry analyses. F.J.F. Ferreira was supported in this research by National Council for Scientific and Technological Development (CNPq), under contract 306978/2015-6.

\section{REFERENCES}

ARCHANJO CJ, SILVA MG, CASTRO JC, LAUNEAU P, TRINDALE RIF \& MACEDO JWP. 2006. AMS and grain shape fabric of the late Paleozoic diamictites of the southeastern Parana Basin, Brazil. Journal of the Geological Society London, p. 95-106.

BORTOLUZZI CA, AWDZIEJ J \& ZARDO SM. 1987. Geologia da Bacia do Paraná em Santa Catarina. Texto explicativo para o mapa geológico do estado de Santa Catarina, escala 1:500.000, p. 131-193.

BUATOIS LA \& MáNGANO MG. 1995. The paleoenvironmental and paleoecological significance of the lacustrine Mermia ichnofacies: An archetypical subaqueous nonmarine trace fossil assemblage. Ichnos, 4(2): 151-161. doi: 10.1080/10420949509380122.

CACELA ASM. 2008. Paleoclima e dinâmica costeira como fatores controladores da distribuição de arenitos em sistemas parálicos: um estudo para reservatórios análigos no Eopermiano da Bacia do Paraná. Universidade Federal do Rio Grande do Sul, Brazil, 118 pp.

CARNEIRO CDR \& DA COSTA FGD. 2006. Estruturas atectônicas da Bacia do Paraná em Campinas (SP): deformação sin-sedimentar no Subgrupo Itararé. Terrae Didática, 2(1): 34-53.

CHAMLEY H. 1989. Clay formation through weathering. In: Clay sedimentology. Springer. p. 21-50.

COLLINSON JW, ISBELL JL, ELLIOT DH, MILLER MF, MILLER JMG \& VEEVERS JJ. 1994. Permian-Triassic Transantarctic Basin. Permian-Triassic Pangean Basins and foldbelts along the Panthalassan margin of Gondwanaland: Geological Society of America Memoir, 184: 173-222.

CROWELL JC. 1999. Pre-Mesozoic ice ages: their bearing on understanding the climate system. Volume 192. Geological Society of America.

DICKINSON WR. 1985. Interpreting provenance relations from detrital modes of sandstones. In: Provenance of arenites. Springer, p. 333-361.

D'ÁVILA RSF. 2009. Sequências deposicionais do Grupo Itararé (Carbonífero e Eopermiano), Bacia do Paraná, na área de Doutor. Pedrinho e cercanias, Santa Catarina. turbiditos, pelitos e depósitos caóticos. Ph.D. thesis. Universidade do Vale do Rio dos Sinos. Porto Alegre, Brazil. 192 pp.

EYLES CH, MORY AJ \& EYLES N. 2003. Carboniferous-Permian facies and tectono-stratigraphic successions of the glacially influenced and rifted Carnarvon Basin, Western Australia. Sedimentary Geology, 155(1-2): 63-86.

FRANÇA AB \& POTTER PE. 1988. Estratigrafia, ambiente deposicional e análise de reservatório do Grupo Itararé (Permocarbonífero), Bacia do Paraná (Parte 1). Boletim de Geociências da Petrobras, 2(2/4): 147-191.

GOLDBERG K. 2001. The paleoclimatic evolution of the Permian in the Paraná Basin in southern Brazil. Ph.D. thesis. University of Chicago, Department of the Geophysical Sciences. 267 pp.

GONÇALVES DF, ROSSETTI DF, TRUCKENBRODT W \& MENDES AC. 2006. Argilominerais da Formação Codó (aptiano superior), Bacia de Grajaú, nordeste do Brasil. Latin American Journal of Sedimentology and Basin Analysis, 13: 59-75. URL http://www.redalyc.org/articulo.oa?id= 381740357003.

HOLZ M \& KALKREUTH W. 2004. Sequence Stratigraphy and Coal Petrology Applied to the Early Permian Coal-bearing Rio Bonito Formation, Paraná Basin, Brazil. In: Sequence Stratigraphy, Paleoclimate, and Tectonics of Coal-Bearing Strata. American Association of Petroleum Geologists.

HOWER J, ESLINGER EV, HOWER ME \& PERRY EA. 1976. Mechanism of burial metamorphism of argillaceous sediment: 1. Mineralogical and chemical evidence. Geological Society of America Bulletin, 87(5): 725-737.

IBRAHIM L. 2008. Argilominerais da porção basal da Formação Corumbatá (Bacia do Paraná) na região de Rio Claro/SP. Universidade Estadual Paulista (UNESP), Brazil. 136 pp.

ISBELL JL, MILLER MF, WOLFE KL \& LENAKER PA. 2003. Timing of late Paleozoic glaciation in Gondwana: Was glaciation responsible for the development of Northern Hemisphere cyclothems? Special papers-Geological Society of America, p. 5-24.

LAVINA EL \& LOPES RDC. 1987. A transgressão marinha do Permiano Inferior e a evolução paleogeográfica do Supergrupo Tubarão no Estado do Rio Grande do Sul. Paula-Coutiana, 1: 51-103. 
LAWVER LA, GAHAGAN LM \& NORTON I. 2011. Chapter 5 Palaeogeographic and tectonic evolution of the Arctic region during the Palaeozoic. Geological Society, London, Memoirs, 35(1): 61-77. doi: 10.1144/M35.5. URL http://mem.lyellcollection.org/content/35/1/61.

LEINZ V. 1937. Estudos sobre a glaciação permo-carbonífera do Sul do Brasil. Departamento Nacional da Produção Mineral. Brazil.

LÓPEZ-GAMUNDÍ OR. 1997. Glacial-postglacial transition in the late Paleozoic basins of southern South America. In: MARTINI IP (Ed.). Late Glacial and Postglacial Environmental Changes, p. 147-168. Oxford University Press.

MEDEIROS RA \& THOMAZ FILHO A. 1973. Fácies e ambientes deposicionais da Formação Rio Bonito. Congresso Brasileiro de Geologia, 27., Aracaju, SE, Brazil. p. 3-12.

MENEZES MTF \& NASCIMENTO M. 2015. Petrografia e diagênese de arenitos Permianos da Bacia do Paraná, região de Alfredo Wagner, Santa Catarina. In: Simpósio Sul-brasileiro de Geologia, 9., SBG-Núcleo RS/SC, Florianópolis, SC, Brazil. Boletim de Resumos. p. 15.

MILANI EJ. 1997. Evolução tectono-estratigráfica da Bacia do Paraná e seu relacionamento com a geodinâmica fanerozóica do Gondwana sul-ocidental. Ph.D. thesis. Universidade Federal do Rio Grande do Sul, Brazil. 255 pp.

MILANI EJ, RANGEL HD, BUENO GV, STICA JM, WINTER WR, CAIXETA JM \& PESSOA NETO OC. 2007. Bacias Sedimentares Brasileiras: Cartas Estratigráficas. Anexo ao Boletim de Geociências da Petrobras, 15(2): 183-198.

PARRY WT \& REEVES CC. 1968. Clay mineralogy of pluvial lake sediments, southern High Plains, Texas. Journal of Sedimentary Research, 38(2): 516-529.

POWELL CM \& LI ZX. 1994. Reconstruction of the Panthalassan margin of Gondwanaland. In: Permian-Triassic Pangean Basins and Foldbelts along the Panthalassan Margin of Gondwanaland. Geological Society of America. doi: 10.1130/MEM184 URL https://doi.org/10.1130/MEM184.

RIDER MH. 1990. Gamma-ray log shape used as a facies indicator: critical analysis of an oversimplified methodology. Geological Society, London, Special Publications, 48(1): 27-37. doi: 10.1144/GSL.SP. 1990.048.01.04. URL http://sp.lyellcollection.org/content/48/1/27.

RUFFELL A \& WORDEN R. 2000. Palaeoclimate analysis using spectral gamma-ray data from the Aptian (Cretaceous) of southern England and southern France. Palaeogeography, Palaeoclimatology, Palaeoecology, 155(3-4): 265-283.

SCHEFFLER K, HOERNES S \& SCHWARK L. 2003. Global changes during Carboniferous-Permian glaciation of Gondwana: Linking polar and equatorial climate evolution by geochemical proxies. Geology, 31(7): 605-608. doi: 10.1130/0091-7613(2003)031<0605:GCDCG0>2.0.C0; 2.

SCHNEIDER R, MUHLMANN H, TOMMASI E, MEDEIROS RAD, DAEMON RF \& NOGUEIRA AA. 1974. Revisão estratigráfica da Bacia do Paraná. Congresso Brasileiro de Geologia, 28., Porto Alegre, Brazil. p. 41-65.

SCHNYDER J, RUFFELL A, DECONINCK JF \& BAUDIN F. 2006. Conjunctive use of spectral gamma-ray logs and clay mineralogy in defining late Jurassic-early Cretaceous palaeoclimate change (Dorset, UK). Palaeogeography, Palaeoclimatology, Palaeoecology, 229(4): 303-320.

SINGER A. 1984. The paleoclimatic interpretation of clay minerals in sediments—a review. Earth-Science Reviews, 21(4): 251-293.

SLONSKI GT. 2002. Interpretação paleoclimática do permiano inferior da Bacia do Paraná em Santa Catarina, Brasil (Formação Rio Bonito). Master's thesis. Centro de Ciências Biológicas, Universidade Federal de Santa Catarina, Brazil. 74 pp.

TUCKER ME. 2001. Sedimentary Petrology: an introduction to the origin of sedimentary rocks. 3rd ed., Oxford, Blackwell, 262 pp.

VELDE B. 1995. Composition and mineralogy of clay minerals. In: VELDE B (Ed.). Origin and mineralogy of clays, Springer-Verlag Berlin Heidelberg. p. 8-42.

VESELY FF \& ASSINE ML. 2004. Sequências e tratos de sistemas deposicionais do Grupo Itararé, norte do Estado do Paraná. Revista Brasileira de Geociências, 34(2): 219-230.

ZALÁN PV, WOLFF S, CONCEIÇÃO JCDJ, ASTOLFI MAM, VIEIRA IS, APPI VT \& ZANOTTO OA. 1987. Tectônica e sedimentação da Bacia do Paraná. In: Simpósio Sul-Brasileiro de Geologia, 3: 441-473.

ZIELINSKI JPT \& NASCIMENTO MS. 2015. Estratigrafia de Sequências Sedimentares Permianas da Borda sudeste da Bacia do Paraná, Santa Catarina. In: Simpósio Sul-brasileiro de Geologia, 9., Sociedade Brasileira de Geologia Núcleo RS/SC, Brazil. Boletim de Resumos. p. 9. 